\title{
A NOTE ABOUT WORDS AND NAMING
}

Words have power. I have taken care with the specific terms I use in The Sea Is My Country. When writing about indigenous peoples, it is most precise to use specific names, such as "Makahs." I have tended to minimize the use of "the Makah" because there really is no single entity that speaks for all individuals who ascribe to this identity. Occasionally, I have needed to use this term, usually in reference to the political body of the tribal nation. I have also used "the People of the Cape," an Anglicized gloss of what they call themselves, Q"idiččara.ťx ("kwi-dihch-chuh-aht"). When referring to more general groups of indigenous peoples, I have used a range of terms interchangeably, including "Natives," "American Indians," and "Indians." All these terms have histories of their own that highlight unequal dynamics of power, racial rhetoric, and identity politics, but alternating them allows me to do more than craft language that flows better. At times, I employed a specific term to invoke the perspectives of a particular group in that historical moment. In addition, I avoided "tribe," instead using "tribal nation" to highlight Native sovereignty and the special political relationship American Indians have with the United States.

Another term worth explaining is "fisher," a word that sounds clunky and awkward to many, including some Makah readers. For this I apologize-in no way am I implying that women who fish today or fished in the past were something less than "fishermen," their male family members. However, the term "fisher" is useful because it helps us acknowledge and discuss how gender shapes the kinds of techniques and gear choices used by different people at specific times in history. I also make an active decision to employ this term here because, as one of my environmental historian colleagues casually noted, "We don't call 'em farmermen or minermen or loggermen." Many younger readers, 
such as students in our classrooms, comfortably use "fisher," so in hopes that this book speaks to future generations who will find the term "fisherman/men" anachronistic, I have used "fisher."

I include a large collection of Makah language terms. Part of the Wakashan language family of the Northwest Coast, Makah is closely related to Nootkan languages of Vancouver Island, particularly Nitinat and Pacheena. Like many Native North American languages, Makah includes sounds that do not appear in English, which is why I have used words in an orthography that looks unfamiliar to many readers. This vocabulary is integral to broadening our understanding of Makah culture and their relationship with marine space, so I have included many words that highlight the Makahs' environmental and geographical knowledge. On first use of these terms, I have italicized common nouns and followed them with the phonetic pronunciation and English equivalent in parenthesis, like this: čitapuk ("chih-tuh-pook," whales). I also included many Makah proper nouns, such as names of people and places. These are capitalized and not set in italics. For these proper nouns, I include a phonetic pronunciation, like this: Ćaqa'wið ("tsuh-kah-wihtl"). I am not fluent in Makah-not even close! However, I worked carefully with Maria Pascua, language specialist at Neah Bay, who patiently explained these terms, helping me sound them out. Any mistakes here are my own. For those interested in learning more about the Makah language, Pascua recommends William H. Jacobsen Jr., First Lessons in Makah (Neah Bay: Makah Cultural and Research Center, 1999).

Last, I would like to point out that as a historian writing about events in the past, I have largely stuck to the past tense, except where the present or future tense was necessary. Many of these past conditions have persisted into the present, however, and affect the future. Makahs continue to shape marine space as the primary site of their identity, and their work and advocacy influence politics and policies in the Northwest Coast. In using the past tense, I am in no way arguing that Makahs no longer exist or are irrelevant today. Similarly, when discussing environmental conditions, I have employed the past tense because I wish to emphasize that past environments were in many cases different from those today. As with human cultures, environmental features and conditions have their own histories. Like the Makahs themselves, these past environments will continue to change and influence circumstances today and in the future. 